\title{
THE EFFECT OF HYDROGEN SULPHIDE ON AMMONIUM BISULPHITE WHEN USED AS AN OXYGEN SCAVENGER IN AQUEOUS SOLUTIONS
}

\author{
B.A. Lasebikana, A.R. Akisanya ${ }^{a^{*}, \text { W.F. Deans }}{ }^{\mathrm{a}}$ and D. E. Macphee ${ }^{\mathrm{b}}$ \\ aSchool of Engineering, University of Aberdeen, Aberdeen AB24 3UE, U.K. \\ bDepartment of Chemistry, University of Aberdeen, Aberdeen AB24 3FX, U.K.
}

\begin{abstract}
The effectiveness of ammonium bisulphite (ABS) as oxygen scavenger and the behaviour of $\mathrm{H}_{2} \mathrm{~S}$ in brine/ABS solutions are examined. Deionised water, $1 \mathrm{wt} \% \mathrm{NaCl}$ and $3.5 \mathrm{wt} \% \mathrm{NaCl}$ with different $\mathrm{ABS}$ concentrations are bubbled with $\mathrm{H}_{2} \mathrm{~S}$ gas, while the dissolved oxygen, sulphide, $E_{H}$ and $\mathrm{pH}$ are measured. With the exception of natural seawater, ABS concentration much greater than $100 \mathrm{ppmw}$ is needed to completely scavenge dissolved oxygen in all the solutions considered. The reaction between ABS and $\mathrm{H}_{2} \mathrm{~S}$ leads to increase in sulphide. The implications of the results for environment assisted cracking of oil and gas production tubings are discussed.
\end{abstract}

\section{Keywords:}
A. Acid solutions
B. Electrochemical calculation
C. Acid corrosion, Pourbaix diagram, sulphidation, sulphide cracking

\section{Introduction}

The continuing need for oil and gas exploration and production is relentless despite the availability of renewable sources of energy. The production of oil and gas involves well completion systems which must be designed to minimise corrosion and consequential

\footnotetext{
* Corresponding Author. Email: a.r.akisanya@abdn.ac.uk. Tel: +44 1224 272989. Fax: +44 1224272495
} 
repair costs. The completion consists of a number of different sized casings inside the conductor used for drilling activities. There is a gradual reduction in the size of the casings with increasing well depth and each casing is cemented at the base to maintain borehole stability. A typical oil and gas well completion configuration is shown in Figure 1. Annuli (A, B, C and D) are required at the top of each casing for well management. The production casing may extend to a depth of $5 \mathrm{~km}$ below the sea bed. The production casing is set in place and usually cemented above the production zone to provide a secondary barrier to well fluid in event of production tubing failure or leak (see Figure 1). Liners are hung off from the bottom of the production tubing and are usually sealed by a liner packer (a form of elastomeric seal) to direct well fluids, i.e. oil and gas, through the liner bore into the production tubing.

The production annulus (i.e. annulus A in Figure 1) normally contains clear brines, e.g. $\mathrm{CaCl}_{2}, \mathrm{NaCl}, \mathrm{NaCl} / \mathrm{NaBr}, \mathrm{CaCl}_{2} / \mathrm{CaBr}_{2}$ etc., and/or treated water (deionised, seawater etc.) to provide hydrostatic head against the ingress of well fluids. The brine or water is treated mainly with oxygen scavenger, usually biocide and corrosion inhibitor [1] to reduce corrosion to negligible levels. The term oxygen scavenger is partially misleading because many of the chemicals used for this purpose in oil and gas wells function mainly as passivating corrosion inhibitors in addition to scavenging of oxygen [2]. A number of chemicals are used as oxygen scavengers, e.g. sodium sulphite $\left(\mathrm{Na}_{2} \mathrm{SO}_{3}\right)$, sodium bisulphite $\left(\mathrm{NaHSO}_{3}\right)$, sodium metabisulphite $\left(\mathrm{Na}_{2} \mathrm{~S}_{2} \mathrm{O}_{5}\right)$, ammonium sulphite $\left(\left(\mathrm{NH}_{4}\right)_{2} \mathrm{SO}_{3} \cdot \mathrm{H}_{2} \mathrm{O}\right)$ and ammonium bisulphite $\left(\mathrm{NH}_{4} \mathrm{HSO}_{3}\right)$.

ABS is one of the most commonly used oxygen scavengers in oil and gas wells completion and production systems. It has the advantage over sodium bisulphite of being miscible with water in concentrated solution, i.e. 65\% (straw coloured), at ambient temperatures as low as $5{ }^{\circ} \mathrm{C}$ which is typical of the North Sea (United Kingdom Continental Shelf) environment. Under similar conditions, sodium bisulphite would precipitate. Therefore this makes ABS the prominent oxygen scavenger used in the North Sea water systems. 
Corrosion control is challenging without sufficient removal of oxygen and/or prevention of oxygen ingress into well completions. ABS is injected into the wellbore production annulus to scavenge any dissolved oxygen in the brine or deionised water (potable water) used in the well completion process or for annulus management during the operation phase respectively. In this application a successful treatment means reducing the oxygen to very low levels. Experience has shown that brine that contains less than 10 ppbw of dissolved oxygen is not corrosive to carbon steel casing and production tubing [2]. However, during oil and gas production, the brine/ABS solution might come into contact with hydrogen sulphide $\left(\mathrm{H}_{2} \mathrm{~S}\right)$ due to acid gas $\left(\mathrm{CO}_{2}\right.$ and $\left.\mathrm{H}_{2} \mathrm{~S}\right)$ ingress from the reservoir to the annulus, e.g. via a leak path such as at the packer seal (Figure 1). ABS has been implicated in downhole failure of production tubing used in a number of high pressure - high temperature (HPHT) well completions due to acid gas ingress to the production annulus [3-5]; the ABS assisted failure was suggested to be due to $\mathrm{ABS}$ degradation at high temperature leading to increase in sulphide.

The interaction between ABS and $\mathrm{H}_{2} \mathrm{~S}$ yields sulphuric acid (Eqns (1) and (2)):

$$
\begin{aligned}
& 4 \mathrm{NH}_{4} \mathrm{HSO}_{3}+3 \mathrm{H}_{2} \mathrm{~S} \rightarrow 4 \mathrm{NH}_{4} \mathrm{HS}+3 \mathrm{H}_{2} \mathrm{SO}_{4} \\
& 4 \mathrm{NH}_{4} \mathrm{HSO}_{3}+4 \mathrm{NaCl}+\mathrm{H}_{2} \mathrm{~S} \rightarrow 4 \mathrm{NH}_{4} \mathrm{Cl}+3 \mathrm{H}_{2} \mathrm{SO}_{4}+2 \mathrm{Na}_{2} \mathrm{~S}
\end{aligned}
$$

Strong acids are aggressive towards steel even in anaerobic conditions. In order to understand the competing effects of oxygen scavenging and acidification more quantitatively and the consequent effect on failure due to corrosion, an investigation of sulphide concentration in this solution is required. Material qualification for production tubing e.g. super duplex stainless steel is usually based on brine chemistry, acid gas partial pressure and designated stress to establish immunity or susceptibility to environment assisted cracking (EAC) in the environment. The addition of other sulphur species may lead to susceptibility to EAC in an environment that it would otherwise be immune. 
An assessment of the degradation associated with the corrosion of a material requires a knowledge and understanding of the characteristics of the environment. The focus of the current work is not on the corrosion behaviour or mechanisms of oil and gas tubulars but on the understanding of the service or operation induced changes in the environment that aids corrosion. It is generally assumed within the oil and gas industry that the addition of 100 ppmw of ABS is sufficient to completely scavenge dissolved oxygen in all types of aqueous solutions used in production annulus. Although this assumption may be true for seawater, there is no evidence that this suggested minimum level of ABS needed to completely scavenge oxygen is valid for other types of aqueous solutions used in the production annulus. The objectives of the current work are two-fold: (i) to determine the minimum concentration of $A B S$ required to completely scavenge oxygen in deionised water, $1 \mathrm{wt} \% \mathrm{NaCl}$ and $3.5 \mathrm{wt} \% \mathrm{NaCl}$ solution, and (ii) to assess the effect of $\mathrm{H}_{2} \mathrm{~S}$ gas on various concentrations of $\mathrm{ABS}$ in these solutions.

\section{Experimental Procedures}

There is currently no National Institute of Standards and Technology (NIST) buffer or standard for determining sulphide levels in acid gas mixtures. Although it is recognised that acid gas mixtures are usually encountered in hydrocarbon reservoirs, ABS/brine solutions were bubbled with $\mathrm{H}_{2} \mathrm{~S}$ gas only in this study. The solutions considered were: deionised water, $1 \mathrm{wt} \% \mathrm{NaCl}$ and $3.5 \mathrm{wt} \% \mathrm{NaCl}$. The ABS concentrations in each type of solution were $0,100,500$ and 1000 ppmw.

Reagent grade $\mathrm{NaCl}$ (supplied by Fisher Scientific) was used to prepare the $1 \mathrm{wt} \% \mathrm{NaCl}$ and $3.5 \mathrm{wt} \% \mathrm{NaCl}$. The ABS (supplied by Baker Petrolite) concentration was varied in the range 0 to $12000 \mathrm{ppmw}$ in each solution and the dissolved oxygen and $\mathrm{pH}$ level, at each concentration of ABS, were measured using an Orion ${ }^{\dagger}$ dissolved oxygen probe and a Russell pH glass bodied electrode (Russell pH, KDCW11) respectively. A magnetic stirrer was engaged prior to and during measurement of dissolved oxygen to ensure

\footnotetext{
${ }^{\dagger}$ Orion Water Environmental Instruments
} 
the dissolved oxygen concentration was representative of the bulk solution. All flasks, glassware, measuring cylinders etc. used for the experiments were carefully cleaned with distilled water and oven dried to prevent cross contamination.

All experiments were carried out using the test loop shown in Figure 2 which was located in a fume cupboard. A combined electrochemical technique and visual observation approach was used in the test program to take measurements and observe chemical reactions.

The reaction vessel (Figure 2) was almost completely filled with the test solutions then closed to prevent air contamination. The reaction cell consisted of the respective solution and a gas tight rubber stopper with access holes for electrodes, thermometer, and gas inlet and outlet tubes. Fitted into the stopper were all the pre-calibrated electrodes for dissolved oxygen, sulphide, $E_{H}$ and $\mathrm{pH}$. The temperature was regulated at $25{ }^{\circ} \mathrm{C}$ with a circulating water bath surrounding the reaction vessel (Figure 2). The manometer was filled with saturated brine before the test started to ensure positive pressure ( 1 atmosphere) was maintained in the test loop.

Nitrogen gas (99.999\% purity) was bubbled at $200-250 \mathrm{ml} /$ minute through the frit in the reaction vessel to deaerate the solution and vented into the fume cupboard through the vent port in the test loop. After approximately one hour, the dissolved oxygen probe was used to confirm the test solution was oxygen free before $\mathrm{H}_{2} \mathrm{~S}$ gas was then introduced at $100 \mathrm{ml} /$ minute. Whilst bubbling, the $\mathrm{H}_{2} \mathrm{~S}$ gas was diverted to the manometer. The saturated brine levels in the manometer were maintained to ensure pressure was maintained at 1 atmosphere in the test cell. Sulphide, $E_{H}$ and $\mathrm{pH}$ measurements were continuously recorded at 15 seconds interval after $\mathrm{H}_{2} \mathrm{~S}$ gas bubbling commenced using a computerised data logger.

The experiments on the determination of the concentration of $\mathrm{ABS}$ required to completely scavenge oxygen were carried out three times while the experiments to 
assess the effect of $\mathrm{H}_{2} \mathrm{~S}$ gas on various concentrations of $\mathrm{ABS}$ were carried out twice on nominally identical solutions, to check for repeatability.

The reliability of the readings depends on accurate calibration of the measuring equipment. All the instruments used in this study were calibrated according to the manufacturer's recommended guidelines and buffer solutions. In particular, the sulphide electrode was calibrated using potassium hydrogen phthalate $(0.05 \mathrm{M}$ $\mathrm{KHC}_{8} \mathrm{H}_{4} \mathrm{O}_{4}$ ) solution in deionised water to obtain a $\mathrm{pH} 4.01$ buffer solution; the sulphide concentration in ppmw was obtained from the measured potential by Nernst equation [6]

$$
E \quad=E_{0}+Q \log (A)
$$

where $E$ is the measured electrode potential in $\mathrm{mV}, E_{0}(=-908.4 \mathrm{mV})$ is the reference potential, $A$ is the level of sulphide in solution in $\mathrm{mol} / \mathrm{litre}\left(1 \mathrm{~mol} / \mathrm{l}=32064 \mathrm{ppmw} \mathrm{\textrm {S } ^ { 2 }}\right)$, and $Q(=-32 \mathrm{mV} /$ decade $)$ is the gradient of $E$ versus $\log (A)$ curve.

\section{RESULTS AND DISCUSSION}

\subsection{Effect of ABS on dissolved oxygen}

The effect of ABS concentration on the dissolved oxygen (without $\mathrm{N}_{2}$ bubbling) and the $\mathrm{pH}$ of deionised water are shown in Figure 3 for three identically prepared solutions. The $\mathrm{pH}$ of the three nominally identical solutions was identical to within less than $1 \%$ and the dissolved oxygen was identical to within $3 \%$ for the range of ABS concentration considered. Similar level of consistency in the measurements was obtained for the repeated tests on the $1 \mathrm{wt} \% \mathrm{NaCl}, 3.5 \mathrm{wt} \% \mathrm{NaCl}$ and natural seawater. Consequently, for clarity, only a representative result of each variable for each of the test solutions is presented in the rest of the paper. 
The effect of ABS concentration on the dissolved oxygen and the $\mathrm{pH}$ of all the test solutions is shown in Figure 4. Both the dissolved oxygen and $\mathrm{pH}$ decrease with increasing $\mathrm{ABS}$ concentration in deionised water, $1 \mathrm{wt} \% \mathrm{NaCl}, 3.5 \mathrm{wt} \% \mathrm{NaCl}$ and natural seawater (North Sea).

The $\mathrm{pH}$ of the natural seawater was 8 whilst it was slightly less than 7 for deionised water (6.9) and $1 \mathrm{wt} \% \mathrm{NaCl}$ (6.8) and slightly above 7 for $3.5 \mathrm{wt} \% \mathrm{NaCl}$ (7.3). A significant reduction in $\mathrm{pH}$ occurred after 100 ppmw ABS was added but little change in $\mathrm{pH}$ at $\mathrm{ABS}$ doses greater than 2000 ppmw; the $\mathrm{pH}$ range was between 4.8 and 5.2 for all solutions at $2000 \mathrm{ppmw}$ ABS and greater. Note that the $\mathrm{pH}$ of undiluted ABS was 4.6.

A significant amount of ABS was required to scavenge the oxygen in deionised water, $1 \mathrm{wt} \% \mathrm{NaCl}$ and $3.5 \mathrm{wt} \% \mathrm{NaCl}$ (see Figure 4a). The average minimum concentration of $\mathrm{ABS}$ required for complete removal of dissolved oxygen in the test solutions is shown in Figure 5. It is generally assumed within the oil and gas industry that the addition of 100 ppmw of ABS is sufficient to completely scavenge aqueous solutions used in the production annulus. The present study shows that this is only the case for natural seawater. It should be noted though that the seawater used in this study did not contain hypochlorite, biocides etc. that can affect the performance of oxygen scavengers in water injection systems [1,7]. The reaction between oxygen and sulphite based scavengers involves a chain (propagation process) mechanism [1], which means they are very sensitive to temperature and the presence of other dissolved species.

Natural seawater contains a range of constituents not present in deionised water or synthetic $\mathrm{NaCl}$ solutions, for example, transition metal ions like cobalt, which can improve the performance of ABS as an oxygen scavenger [2]. This is supported by the above findings which show that considerably greater ABS concentrations are required to remove dissolved oxygen in deionised water and synthetic brines. Further, greater addition of oxygen scavenger led to a decrease in $\mathrm{pH}$, which reduces the efficiency of scavenging as indicated by Snavely [8] for sulphite based scavengers below pH 7. 
As the ABS concentration increases, the reduction in redox potential $\left(E_{H}\right)$ becomes less significant, as indicated in Figure 6. The highest rate of $E_{H}$ reduction is observed for the first 100 ppmw ABS (for which there is a similar significant decrease in $\mathrm{pH}$ ), with a more gradual reduction in $E_{H}$ with further increases in ABS concentration. ABS is a reducing agent, typical of many oxygen scavengers [2], the bisulphite ion being oxidised to bisulphate:

$$
2 \mathrm{HSO}_{3}{ }^{-}{ }_{\text {(aq) }}+\mathrm{O}_{2} \text { (aq) } \rightarrow 2 \mathrm{HSO}_{4}{ }^{-}{ }_{\text {(aq) }} \text {. }
$$

In this reaction, sulphur is oxidised ( $\mathrm{S}(\mathrm{IV}) \rightarrow \mathrm{S}(\mathrm{VI})+2 \mathrm{e}^{-}$) and the oxygen is reduced $\left(\mathrm{O}_{2(\mathrm{aq})}+2 \mathrm{e}^{-} \rightarrow \mathrm{O}^{2^{-}}\right.$(aq) $)$in formation of sulphate. The drop in the rate of conversion of $\mathrm{O}_{2(\mathrm{aq})}$ to $\mathrm{O}^{2-}$ at higher $\mathrm{ABS}$ concentrations may be attributed to the increasing scarcity of $\mathrm{O}_{2(\mathrm{aq})}$ in these more heavily dosed $\mathrm{ABS}$ systems. It is important to note also that $\mathrm{pH}$ has an important influence on the electrochemical stability of the various sulphur species, which has an impact on electrochemical potential. However, the results of the current experiment have shown that $\mathrm{pH}$ remains relatively constant at between 4.8 and 5.4 above very low additions (100 ppmw) of ABS.

\subsection{Effect of $\mathrm{H}_{2} \mathrm{~S}$ on sulphide in $\mathrm{NaCl} / \mathrm{ABS}$ solution}

A reliable quantitative measurement and qualitative assessment of sulphide requires strictly controlled environmental conditions. Complete oxygen removal and oxygen ingress was prevented during all the experimental work to prevent formation of other sulphur compounds. In addition to electrochemical measurements (dissolved oxygen, sulphide, $E_{H}$ and $\mathrm{pH}$ ) an important aspect of the testing was visual observation of the solutions prior to and during $\mathrm{H}_{2} \mathrm{~S}$ bubbling. The dissolved oxygen probe was used to measure dissolved oxygen levels in solution during the deaeration phase only, whilst all the other measurements were recorded simultaneously at intervals during the $\mathrm{H}_{2} \mathrm{~S}$ bubbling phase. Recall that complete deaeration was achieved by the addition of nitrogen gas. 
The $\mathrm{pH}$, sulphide concentration and oxidation reduction potential, $E_{H}$, for two nominally identical solutions of deionised water containing 1000 ppmw ABS are shown in Figure 7. Note that $\mathrm{H}_{2} \mathrm{~S}$ bubbling started after about 40 mins from the start of the test; this corresponded to when there was complete deaeration. The good level of consistency in the measurements shown in Figure 7 was also obtained for the other solutions considered in part of the current study. Hereafter, only representative results of the $\mathrm{pH}$, sulphide concentration and $E_{H}$ for each of the test solutions is presented.

The $\mathrm{pH}$ from the start of deaeration is shown in Figure 8 for all the solutions. The arrows in Figure 8 indicate the moment when $\mathrm{H}_{2} \mathrm{~S}$ was introduced, which corresponds to the end of deaeration. After deaeration, the $\mathrm{pH}$ of ABS-free deionised water, $1 \mathrm{wt} \%$ $\mathrm{NaCl}$ and $3.5 \mathrm{wt} \% \mathrm{NaCl}$ solutions were 7.4, 7.88 and 7.98 respectively. The $\mathrm{pH}$ of the ABS-free solutions increased with increasing level of deaeration due to decrease in solution conductivity with deaeration. During $\mathrm{H}_{2} \mathrm{~S}$ gas bubbling, the $\mathrm{pH}$ of the ABS-free deionised water decreased until the termination of the test. As indicated in equation (1), this is due to the formation of an acidic solution.

The initial level of dissolved oxygen in the solutions containing various concentrations of $\mathrm{ABS}$ (100, 500 and $1000 \mathrm{ppmw})$ is summarised in Table 1. Some deaeration was still necessary to ensure the solution was oxygen free before $\mathrm{H}_{2} \mathrm{~S}$ was introduced. When $\mathrm{H}_{2} \mathrm{~S}$ bubbling commenced (after complete deaeration) there was a decrease in $\mathrm{pH}$ in all solutions; the extent of which corresponded with the level of ABS in the solution. However, the decrease in $\mathrm{pH}$ was only temporary (see Figure 8). As indicated in equation (2), although the reaction results in an acidic solution the $\mathrm{pH}$ stabilises due to the formation of sodium sulphide $\left(\mathrm{Na}_{2} \mathrm{~S}\right)$, the alkalinity of which counteracts the effects of sulphuric acid. The solution with the highest concentration of ABS experienced the lowest $\mathrm{pH}$ and the longest extended period before increase in $\mathrm{pH}$ was observed. Consequently, it is shown that $\mathrm{ABS}$ had more effect on the $\mathrm{pH}$ of all the solutions than $\mathrm{H}_{2} \mathrm{~S}$. 
$\mathrm{ABS}$ is routinely used in the oil and gas industry to scavenge dissolved oxygen in brines used in well completions. $\mathrm{ABS}$ is a corrosive liquid because of the low $\mathrm{pH}$ it generates in the formation of reaction products. As metabisulphite is oxidised to metabisulphate in the presence of oxygen, the acidification effects of metabisulphate produces sulphuric acid. In the current experiment the aqueous medium was deaerated completely. If the scavenging reaction does not proceed to completion, sulphite and oxygen can coexist in treated water and brine [2] further exacerbating oxygen corrosion risk in well completion production casing usually made of carbon steel and stress corrosion cracking risk in well completion production tubing which is usually made of duplex stainless steels.

\subsection{Oxidation reduction potential $\left(E_{H}\right)$}

The redox potential in all the solutions considered is shown in Figure 9. The sulphide and bisulphite in the solutions with ABS form a couple that results in a reducing environment that continued until test termination. The addition of $\mathrm{H}_{2} \mathrm{~S}$ gas into the solutions with $100 \mathrm{ppmw}$ ABS led to a significant decrease in $E_{H}$, followed by precipitation of sulphur in the $\mathrm{NaCl}(1$ and $3.5 \mathrm{wt} \%$ ) solutions and subsequent minimal change in $E_{H}$. Whereas, in the solutions with 500 and 1000 ppmw ABS there was an initial decrease in $E_{H}$ during precipitation of sulphur (see Figure 8), followed by a further decrease until termination of the test. Overall the change in $E_{H}$ in the $100 \mathrm{ppmw}$ $\mathrm{ABS} / \mathrm{H}_{2} \mathrm{~S}$ solutions was not significant after precipitation compared to the 500 and 1000 ppmw $\mathrm{ABS} / \mathrm{H}_{2} \mathrm{~S}$ solutions where significant change in $E_{H}$ occurred after precipitation. It appeared from visual observation that there was more elemental sulphur in the $\mathrm{NaCl}$ solutions during precipitation. The precipitation occurred sooner as the ABS concentration in the $\mathrm{NaCl}$ solutions increased and for a longer period. The tests were terminated when the change in $E_{H}$ was negligible. The $E_{H}$ continued to decrease until the termination of the test in the ABS free solution. 


\subsection{Sulphide}

Similar to the $\mathrm{pH}$ and $E_{H}$ measurements the sulphide measurements in the solution under consideration followed the same trend (Figure 10). Note that there was no increase in sulphide in the ABS-free solutions; thus this has been omitted from Figure 10. An increase in sulphide was recorded in all solutions with ABS; however the increase in sulphide was measured sooner in all solutions with 100 ppmw ABS compared to those with 500 and 1000 ppmw ABS due to minimal precipitation. Recall that $\mathrm{H}_{2} \mathrm{~S}$ bubbling was carried out at $100 \mathrm{ml} / \mathrm{min}$ for all the solutions considered. The rate of increase of sulphide with continued bubbling of the $\mathrm{H}_{2} \mathrm{~S}$ was found to be approximately $10 \mathrm{ppbw} / \mathrm{min}$, independent of the chloride and ABS concentrations in the solution (see Figure 10).

When $\mathrm{H}_{2} \mathrm{~S}$ was bubbled through all the solutions with $\mathrm{ABS}$ included, a white turbidity of sulphur was seen after a short period. Depending on equilibrium conditions, sulphur may exist in various oxidation states in aqueous complex species (see Table 2). If equilibrium were attained, only $\mathrm{H}_{2} \mathrm{~S}, \mathrm{HS}^{-}, \mathrm{S}^{2-}, \mathrm{S}, \mathrm{HSO}_{4}{ }^{-}$and $\mathrm{SO}_{4}{ }^{2-}$ ought to be found in solution according to the Pourbaix diagram for sulphur and water at $25{ }^{\circ} \mathrm{C}$ for ideal solutions [9], see Figure 11. In acid solutions, the total sulphide is present mainly in the form of $\mathrm{H}_{2} \mathrm{~S}$ but as the $\mathrm{pH}$ increases the principle species present is $\mathrm{HS}^{-}$and only in very basic solution does the total sulphide exist mainly in the form of free sulphide ion $\left(\mathrm{S}^{2-}\right)$.

Heunisch [10] noted that when the $\mathrm{pH}$ dips below about 6 , generally after the $\mathrm{HSO}_{3}{ }^{-} / \mathrm{HS}^{-}$mole ratio has been exceeded and excess $\mathrm{HSO}_{3}{ }^{-}$ion is added, a finely divided, white precipitate of elemental sulphur forms and will not redissolve on standing. It has also been reported that elemental sulphur is formed predominantly from the sulphide-sulphite system in acidic solutions where the sulphide is present in excess [11]. From Figures 8 and 9, the onset of precipitation (i.e. presence of sulphur) coincides with the occurrence of the minimum $\mathrm{pH}$ which then increases thereafter and stabilises; this is consistent with Heunisch's results. 
There will always be the same total amount of sulphur species in each solution but the amount present as sulphide and sulphur will vary with the $\mathrm{pH}$ (Figure 8)[2,12]. There was more sulphide in the deionised water compared to the $1 \mathrm{wt} \% \mathrm{NaCl}$ and $3.5 \mathrm{wt} \%$ $\mathrm{NaCl}$ solutions (Figure 10). In deionised water the sulphur was mainly in solution as bisulphide, see equation (1), whereas in the $\mathrm{NaCl}$ solutions it appears that there was less sulphide in solution (being less milky by visual observation) and more sulphur precipitated as the concentration of ABS increased from 100 to 1000 ppmw. Table 3 shows the results of the tests in $3.5 \mathrm{wt} \% \mathrm{NaCl}$ solution with 1000 ppmw ABS and $\mathrm{H}_{2} \mathrm{~S}$ gas bubbling after deaeration. Note the initial increase in the absolute sulphide potential, then a decrease before a steady increase. This trend was observed in all solutions (deionised water, 1 and 3.5 wt $\% \mathrm{NaCl}$ ) with ABS especially when 500 or $1000 \mathrm{ppmw}$ was added to the test solution. The $\mathrm{pH}$ followed a similar trend (Figure 8) i.e. an initial decrease followed by an increase. The initial decrease in sulphide was due to the initiation of precipitation (opalescence) and low $\mathrm{pH}$. When the bubbling with $\mathrm{H}_{2} \mathrm{~S}$ gas starts, it lowers the $\mathrm{pH}$, which will decrease the sulphide present in the solution as more sulphur, in $\mathrm{HS}^{-}$and $\mathrm{H}_{2} \mathrm{~S}$ species forms in addition to the precipitate. The initial decrease in $\mathrm{pH}$ also coincides with where the solution started to turn milky, i.e. precipitation. The beginning of precipitation was stronger and quicker in line with higher concentration of ABS in all solutions. The precipitation was observed when the measured $E_{H}$ and $\mathrm{pH}$ values were in the range $-300 \leq E_{H} \leq-100$ and $4 \leq \mathrm{pH} \leq 6$ respectively; this is included in the Pourbaix diagram shown in Figure 11. The experimental results indicate a transition from $\mathrm{H}_{2} \mathrm{~S}$ to $\mathrm{S}$ in the solutions; this is consistent with the white turbidity observed in the experiment.

Elemental sulphur is only stable under mildly oxidising to mildly reducing conditions at a pH below 8. The measured $\mathrm{pH}$ (Figure 8 ) and $E_{H}$ (Figure 9) of the $\mathrm{ABS}-\mathrm{H}_{2} \mathrm{~S}$ solutions (with 500 and 1000 ppmw ABS) for deionised water, $1 \mathrm{wt} \% \mathrm{NaCl}$ and $3.5 \mathrm{wt} \% \mathrm{NaCl}$ solutions in the current study correspond to the area of the Pourbaix diagram which predicts stable $\mathrm{H}_{2} \mathrm{~S}$ and sulphur precipitation (Figure 11). 
Since the amount of sulphur present in the sulphide form is very $\mathrm{pH}$ dependent, this is most likely the cause of sulphide being measured in the sample containing ABS. The addition of $\mathrm{H}_{2} \mathrm{~S}$ to the solutions with $\mathrm{ABS}$ only results in momentary change in the $\mathrm{pH}$ of the solutions, which allows for sulphide to be present in a condition when it otherwise would not be. Precipitation of sulphur was more obvious in the $1 \mathrm{wt} \% \mathrm{NaCl}$ and $3.5 \mathrm{wt} \% \mathrm{NaCl}$ solutions plus ABS albeit actual measured sulphide was less compared to the deionised water solutions (Figure 12). It appears that sulphur stayed more in solution as sulphide in the deionised water compared to $1 \mathrm{wt} \% \mathrm{NaCl}$ and $3.5 \mathrm{wt} \% \mathrm{NaCl}$ solution.

\section{Implications for corrosion in oil and gas well completion systems}

The results of this investigation showed the formation of sulphur and sulphide in $\mathrm{NaCl} / \mathrm{ABS}$ mixed with $\mathrm{H}_{2} \mathrm{~S}$ gas. The amount of sulphur and sulphide is found to be a function of the $\mathrm{pH}$, which in turn depends on the ABS concentration. This has major implications for the corrosion behaviour of oil and gas completion tubulars where the ingress of $\mathrm{H}_{2} \mathrm{~S}$ into the production annulus containing brine solution is not uncommon.

The measurements performed by Brunner et al. [13] showed that sulphur solubility in $\mathrm{H}_{2} \mathrm{~S}$ gas decreases with decrease in temperature and pressure. If there was $\mathrm{H}_{2} \mathrm{~S}$ gas ingress into the annulus (due to packer damage) of a well completion, the gas stream will cool down and the pressure will drop as it rises in the annulus. It is conceivable therefore that sulphur may be deposited on the tubing. Kolts [14] found elemental sulphur increased the risk of crevice attack in corrosion resistant alloys including DSS. Mahmoud [15] and Ueda et al. [16] concluded that pitting and crevice corrosion occurred at surface areas of high nickel alloys that had been in direct contact with elemental sulphur in the presence of chlorides. Coyle [17] also found that the presence of sulphur increases the susceptibility of high nickel alloys to SCC.

In HPHT well completions the solubility of $\mathrm{H}_{2} \mathrm{~S}$ and $\mathrm{CO}_{2}$ will be affected by pressure and temperature. The solubility of gases increases with increasing pressure. Henry's law states that under ideal conditions, the solubility of a gas in a liquid is directly 
proportional to the pressure of that gas above the surface of the solution. Henry's law is limited to dilute systems at low pressures. Therefore at HPHT conditions the nonideality of gases begins to affect solubility [18]. Nelson et al. [19] showed that the Henry's law over predicts the concentration of dissolved $\mathrm{H}_{2} \mathrm{~S}$ in water above $10.3 \mathrm{MPa}$ (103 bar) and determined that the ensemble Henry's law is the most accurate description of gas-liquid equilibrium at high pressure. Although the tests in the current study were carried out at 1 atmosphere and $25{ }^{\circ} \mathrm{C}$ it is surmised that if the concentration of the $\mathrm{H}_{2} \mathrm{~S}$ at HPHT is reproduced correctly in a laboratory test, the reaction products between $\mathrm{ABS}$ and $\mathrm{H}_{2} \mathrm{~S}$ should be similar.

\section{Conclusions}

The aqueous reaction of ABS (various concentrations) in deionised water, $1 \mathrm{wt} \% \mathrm{NaCl}$ and $3.5 \mathrm{wt} \% \mathrm{NaCl}$ and $\mathrm{H}_{2} \mathrm{~S}$ has been investigated. Through the course of the experiments, sulphide was measured in solutions that included ABS. Increase in sulphide was not measured in blank solutions in all experiments. Nevertheless, the main conclusions are as follows:

1. Although it is generally assumed within the oil and gas industry that the addition of 100 ppmw ABS is sufficient to completely scavenge aqueous solutions used in the production annulus, a concentration of 100 ppmw ABS or less does not scavenge the dissolved oxygen to less than $10 \mathrm{ppbw}$ in deionised water, $1 \mathrm{wt} \% \mathrm{NaCl}$ and $3.5 \mathrm{wt} \% \mathrm{NaCl}$ solutions. This new finding would enable a more effective use of ABS as oxygen scavenger to mitigate corrosion in oil and gas completion systems.

2. There is a relationship between the amounts of sulphide measured and ABS concentration in all $\mathrm{H}_{2} \mathrm{~S}$ solutions at low $\mathrm{pH}$. The sulphide level increases as the ABS concentration increases.

3. In all solutions the level of precipitation of sulphur increased as the ABS concentration increased. 
4. There were more sulphides in deionised water set of solutions with ABS, i.e. 100, 500 and 1000 ppmw ABS compared to $1 \mathrm{wt} \% \mathrm{NaCl}$ and $3.5 \mathrm{wt} \% \mathrm{NaCl}$ solutions with similar concentration of ABS.

5. Though less sulphide was measured in the $\mathrm{NaCl}$ solutions compared to deionised water solutions, sulphur was more discernable in line with increase in ABS concentration (100 to 1000 ppmw ABS) in $\mathrm{NaCl}$ solutions.

6. In $\mathrm{ABS} / \mathrm{H}_{2} \mathrm{~S}$ solutions, the $\mathrm{ABS}$ behaved like a $\mathrm{pH}$ buffer in solution due to relatively constant $\mathrm{pH}$ of the solutions during $\mathrm{H}_{2} \mathrm{~S}$ bubbling until the termination of the test.

ABS is routinely used in the oil gas industry to scavenge dissolved oxygen in brines used in well completions or deionised water (potable water) used in the production annulus for well management in the operation phase. In the presence of $\mathrm{H}_{2} \mathrm{~S}$, the bisulphite is reduced to sulphide and sulphur thus ABS should be included in material qualification test programs of production tubing especially where $\mathrm{H}_{2} \mathrm{~S}$ presence is identified. Oxygen scavengers without a sulphite component should be considered for use in well completions production annulus during the operation phase. However, if no suitable alternative exists then ABS concentration should not exceed $100 \mathrm{ppmw}$ in solution (with chloride less than $0.1 \mathrm{wt} \% \mathrm{NaCl}$ ) and all the oxygen scavenged.

\section{ACKNOWLEDGMENTS}

The authors gratefully acknowledge the financial support of Shell UK, Gary Smith of the Department of Chemistry, University of Aberdeen for the set-up of the test loop, and to Norma Thomson for the supply of the chemicals.

\section{REFERENCES}

[1] T.G. Braga, Effects of commonly used oilfield chemicals on the rate of oxygen scavenging by sulphite/bisulphite. SPE Production Engineering 5 (1987) 137-142. 
[2] NACE International Task Group T-3A-6. Oxygen scavengers in steam generating systems and in oil production. Item No. 24177. NACE International, 1994

[3] D.E. Mowat, M.C. Edgerton, E.H.R. Wade, Erskine field HPHT workover and tubing corrosion failure investigation, Paper No. 67779. Proceedings of SPE/IADC Drilling Conference, Amsterdam, The Netherlands, 27 Feb - 1 Mar 2001.

[4] R. Mack, C. Williams, S. Lester, J. Casassa, Stress corrosion cracking of a cold worked 22Cr duplex stainless steel production tubing in high density clear brine $\mathrm{CaCl}_{2}$ packer fluid, NACE International, Paper No. 2067, Corrosion 2002, Denver, Colorado. 7-11 April 2002.

[5] I.M. Hannah, D.A. Seymour, D.A., Shearwater super duplex tubing failure investigation, NACE International, Paper No. 06491, Corrosion 2006, San Diego, California, 12- 16 March 2006.

[6] D. Wahl, A short history of electrochemistry - Part 2, Galvanotechtnik 96 (2005) $1820-1818$.

[7] R.L. Miron, Removal of aqueous oxygen by chemical means in oil production operations, SPE Reprint Series 46 (1997) 99-104.

[8] E.S.J. Snavely, Chemical removal of oxygen from natural waters, J. Petroleum Technology 23 (1971) 443-446.

[9] M.J.N. Pourbaix, Atlas of electrochemical equilibria in aqueous solutions, Pergamon Press Ltd.; Great Britain, 1966.

[10] G.W. Heunisch, Stoichiometry of the reaction of sulphites with hydrogen sulphide ion, Inorganic Chemistry 16 (1977) 1411-1413.

[11] E.F. Riesenfeld, G.W. Feld, A quantitative study of the formation of polythionic acids by the action of hydrogen sulphide on sulphur dioxide in water solution, $\mathrm{Z}$. Anorg. Allg. Chem. (1921) 119 - 225. 
[12] Orion. 9614A Sulphide ion activity electrode, Orion Research Incorporated, 1996.

[13] E. Brunner, M.C. Place Jr., W.H. Woll, Sulphur solubility in sour gas. J. Petroleum Technology 1 (1998)1587-1592.

[14] J. Kolts, Laboratory investigation of corrosion resistant alloys for the oil and gas industry. Paper No. 323. Corrosion 1986, Houston. NACE International, 1986.

[15] S.E. Mahmoud, H.E. Chung, C.W. Petersen, Localised corrosion of corrosion resistant alloys in sulphur-chloride-containing environments, NACE International. Paper No. 70. Corrosion 1990, Las Vegas, Nevada. 23 - 27 April 1990.

[16] M. Ueda, T. Kudo, Effect of Alloying Element on corrosion resistance of Ni based alloy in sulphur containing sour environments, NACE International, Paper No. 69, Corrosion 1994, Baltimore, Maryland, 27 March - 4 April 1994.

[17] W.R. Coyle, Effect of free sulphur on cracking behaviour of CRA'S in simulated downhole environments, NACE International, Paper No. 131, Corrosion 1993, New Orleans, Louisiana. 7 - 12 March 1993.

[18] J.J. Carroll, What is Henry's law?, Chemical Engineering Progress 87 (1991) 48-52.

[19] J.L. Nelson, R.V. Reddy, Selecting representative laboratory test conditions for fitfor-purpose OCTG material evaluations, SPE 97576, SPE High Pressure/High Temperature Sour Well Design Applied Technology Workshop, Woodlands, 17 19 May 2005. 


\section{List of Figures}

Figure 1 Typical well completion system.

Figure 2 A schematic of the test flow loop set-up.

Figure 3 Effect of ABS concentration on (a) dissolved oxygen level and (b) $\mathrm{pH}$, for deionised water. The results are for three identically prepared solutions and experiments.

Figure 4 Effect of ABS concentration on (a) dissolved oxygen level and (b) pH, for all the test solutions.

Figure 5 ABS concentration required to scavenge dissolved oxygen in different brine solutions

Figure 6 The effect of ABS concentration on the oxidation reduction potential $E_{H}$ in $3.5 \mathrm{wt} \% \mathrm{NaCl}$ solution.

Figure 7 The effect of $\mathrm{H}_{2} \mathrm{~S}$ on the (a) $\mathrm{pH}$ and oxidation reduction potential $E_{H}$, and (b) the sulphide concentration for two nominally identical solutions of deionised water containing 1000 ppmw of ABS. $\mathrm{H}_{2} \mathrm{~S}$ bubbling commenced after complete deaeration at about 40 mins after the start of the tests.

Figure 8 The $\mathrm{pH}$ during deaeration and $\mathrm{H}_{2} \mathrm{~S}$ bubbling (arrows indicate where $\mathrm{H}_{2} \mathrm{~S}$ bubbling starts). (a) Deionised water, (b) 1 wt\% NaCl, (c) 3.5 wt $\% \mathrm{NaCl}$. Continuous line arrows indicate where $\mathrm{H}_{2} \mathrm{~S}$ bubbling starts and dashed arrows indicate the onset of precipitation. 
Figure 9 Oxygen reduction potential, $E_{H}$, during deaeration and $\mathrm{H}_{2} \mathrm{~S}$ bubbling. (a) Deionised water, (b) $1 \mathrm{wt} \% \mathrm{NaCl}$, and (c) $3.5 \mathrm{wt} \% \mathrm{NaCl}$. Continuous line arrows indicate where $\mathrm{H}_{2} \mathrm{~S}$ bubbling starts and dashed arrows indicate the onset of precipitation.

Figure 10 Sulphide concentrations after the start of $\mathrm{H}_{2} \mathrm{~S}$ bubbling in (a) deionised water, (b) $1 \mathrm{wt} \% \mathrm{NaCl}$, and (c) $3.5 \mathrm{wt} \% \mathrm{NaCl}$. Arrows indicate where $\mathrm{H}_{2} \mathrm{~S}$ bubbling starts.

Figure 11 Pourbaix $E_{H}-\mathrm{pH}$ diagram for sulphur water system at $25{ }^{\circ} \mathrm{C}$ and 1 atmosphere (Adapted from [9]). The shaded region represents experimental measurements for the test solutions: $3.5 \mathrm{wt} \% \mathrm{NaCl}+1000$ ppmw ABS, $1 \mathrm{wt} \% \mathrm{NaCl}+1000$ ppmw ABS, $3.5 \mathrm{wt} \% \mathrm{NaCl}+500$ ppmw ABS, deionised water +1000 ppmw ABS, and $1 \mathrm{wt} \% \mathrm{NaCl}+500$ ppmw ABS.

Figure 12 The sulphide concentration in various solutions after termination of test. 
Table 1: Initial level of dissolved oxygen before further deaeration with nitrogen gas

\begin{tabular}{|lccc|}
\hline Solution & \multicolumn{3}{c|}{ ABS Concentration (ppmw) } \\
& $\mathbf{1 0 0}$ & $\mathbf{5 0 0}$ & $\mathbf{1 0 0 0}$ \\
Deionised Water [ppbw] & 5740 & 5720 & 5990 \\
$1 \mathrm{wt} \% \mathrm{NaCl}[\mathrm{ppbw}]$ & 5750 & 5830 & 5150 \\
$3.5 \mathrm{wt} \% \mathrm{NaCl}[\mathrm{ppbw}]$ & 4440 & 4510 & 4100 \\
\hline
\end{tabular}


Table 2: Sulphur species

\begin{tabular}{|ccl|}
\hline $\begin{array}{c}\text { Sulphur Oxidation } \\
\text { Number }\end{array}$ & Formula & \multicolumn{1}{c|}{ Name } \\
+6 & $\mathrm{SO}_{4} 2^{--}$ & Sulphate \\
+5 & $\mathrm{~S}_{2} \mathrm{O}_{6} 2^{-}$ & Dithionate \\
+4 & $\mathrm{SO}_{2}$ & Sulphur dioxide \\
+4 & $\mathrm{SO}_{3} 2^{-}$ & Sulphite \\
+2.5 & $\mathrm{~S}_{4} \mathrm{O}_{6} 2^{-}$ & Tetrathionate \\
+2 & $\mathrm{~S}_{2} \mathrm{O}_{3^{2}}$ & Thiosulphate \\
0 & $\mathrm{~S}^{-}$ & Sulphur \\
$-2 / 3$ & $\mathrm{~S}_{2} 2^{-}$ & Polysulphides \\
-1 & $\mathrm{~S}_{2} 2^{-}$ & Polysulphides \\
-2 & $\mathrm{~S}^{2^{-}}$ & Sulphide \\
\hline
\end{tabular}


Table 3: Test data for $3.5 \mathrm{wt} \% \mathrm{NaCl}$ with $1000 \mathrm{ppmw}$ ABS added

\begin{tabular}{|lccccc|}
\hline Activity & $\begin{array}{c}\text { Time } \\
\text { (Minutes) }\end{array}$ & $\begin{array}{c}\text { Dissolved } \\
\text { Oxygen } \\
\text { (ppbw) }\end{array}$ & pH & S (mV) & Comments \\
Before & 0 & 4100 & 4.486 & & \\
deaeration & 21 & 0 & 4.502 & & \\
& 37 & 0 & 4.575 & & \\
$\mathrm{H}_{2}$ S bubbling & 47 & 0 & 4.569 & -407.3 & \\
starts & 52 & 0 & 4.574 & -425.9 & \\
& 57 & 0 & 3.825 & -394.1 & Opalescence starts \\
& 61 & 0 & 3.755 & -390.3 & Opalescence increases \\
& 65 & 0 & 3.728 & -392.8 & \\
& 68 & 0 & 3.900 & -405.3 & \\
& 74 & 0 & 4.204 & -423.3 & \\
& 82 & 0 & 4.853 & -487.9 & \\
& 89 & 0 & 4.938 & -502.6 & \\
& 94 & 0 & 4.943 & -516.4 & \\
& 97 & 0 & 4.916 & -519.7 & \\
& 100 & 0 & 4.882 & -522.6 & \\
\hline
\end{tabular}




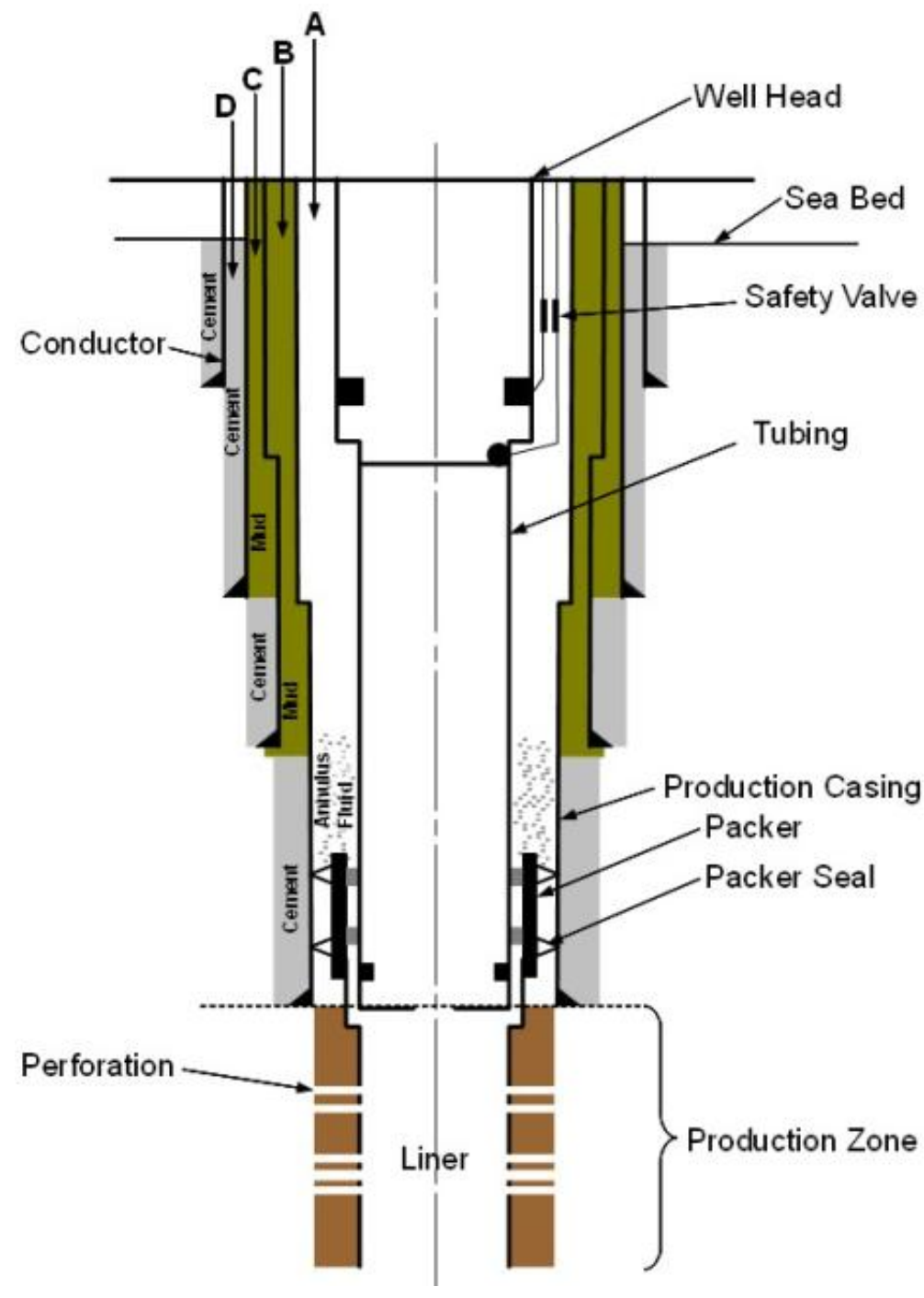

Figure 1 


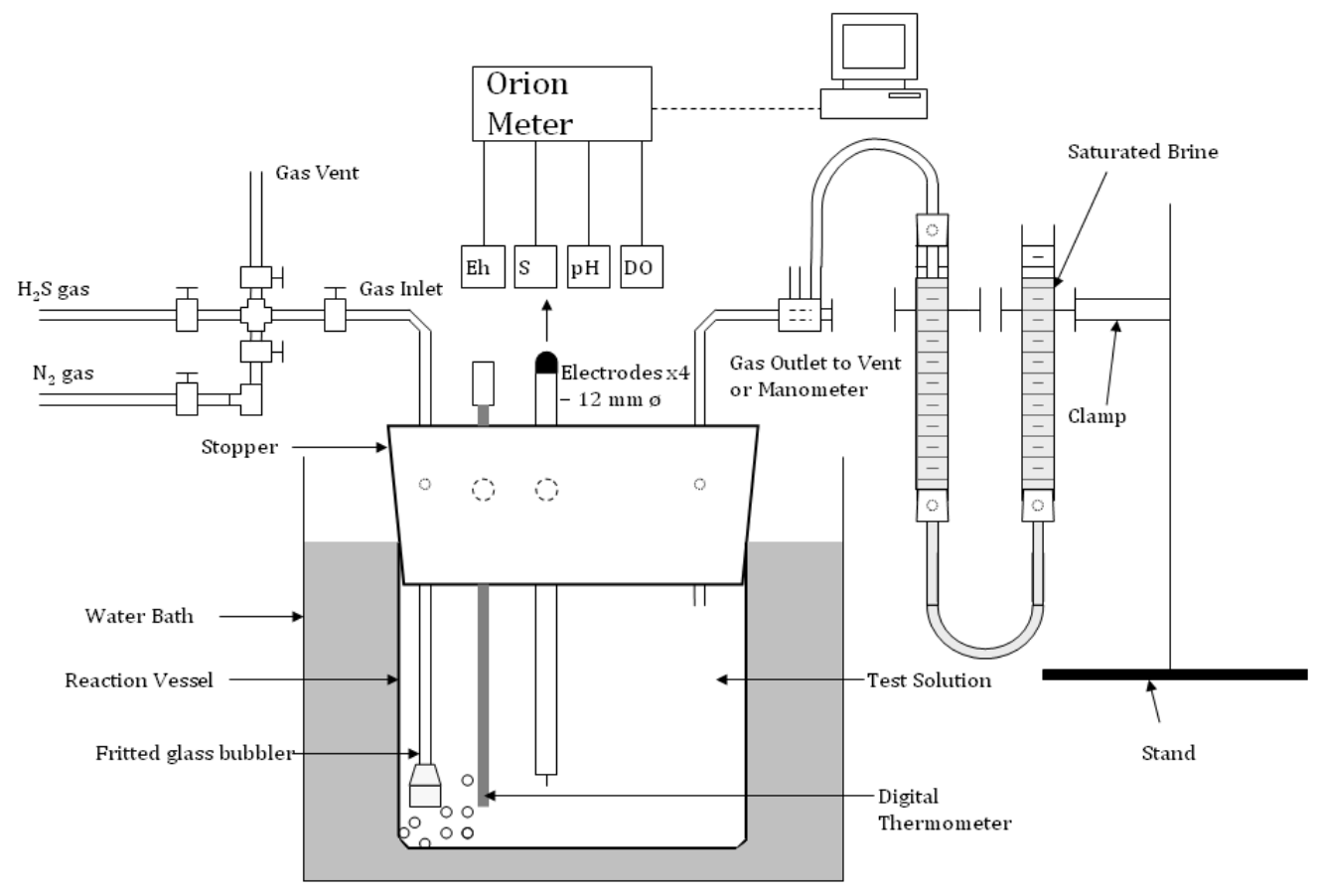

Figure 2 

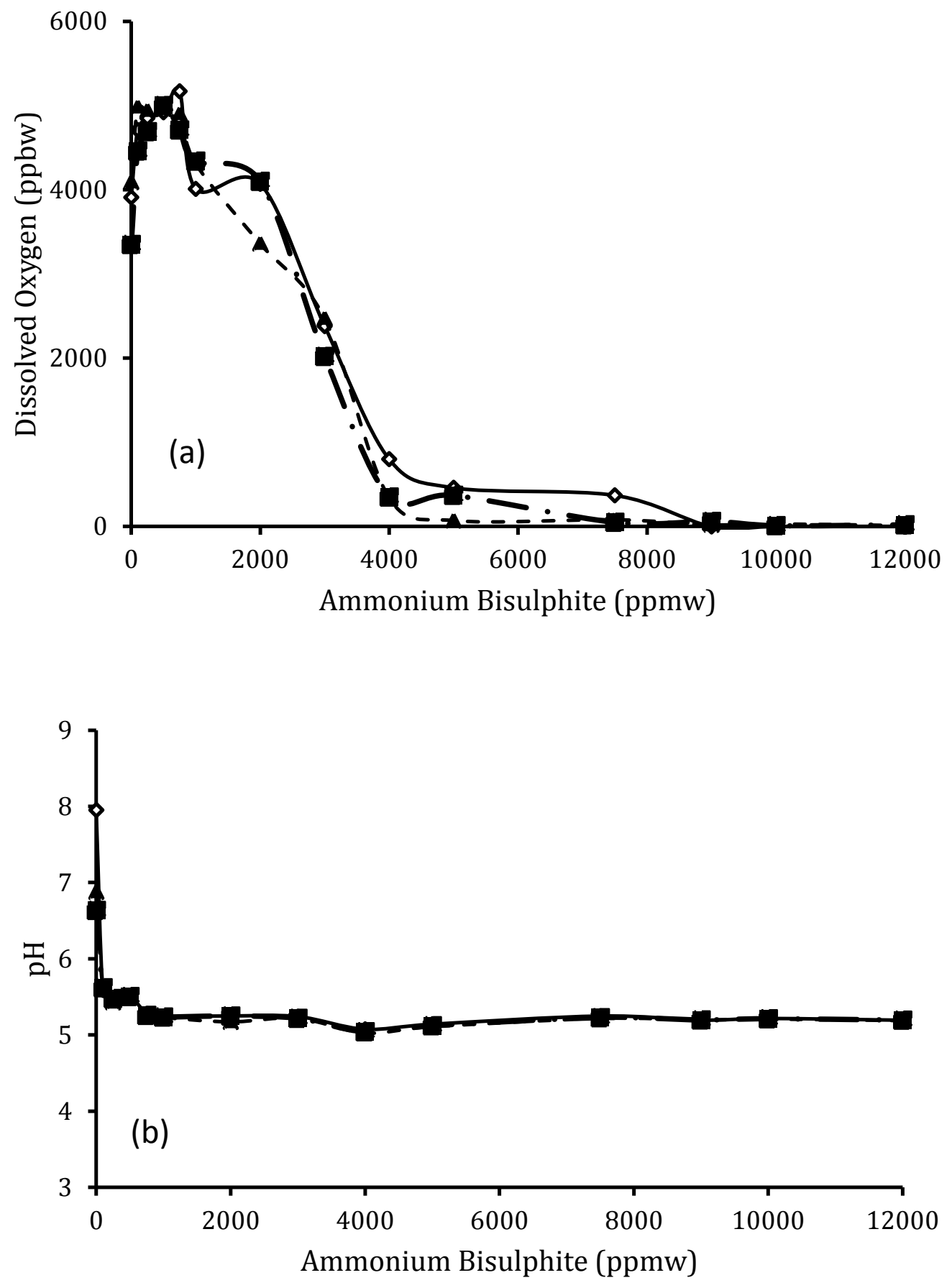

Figure 3 

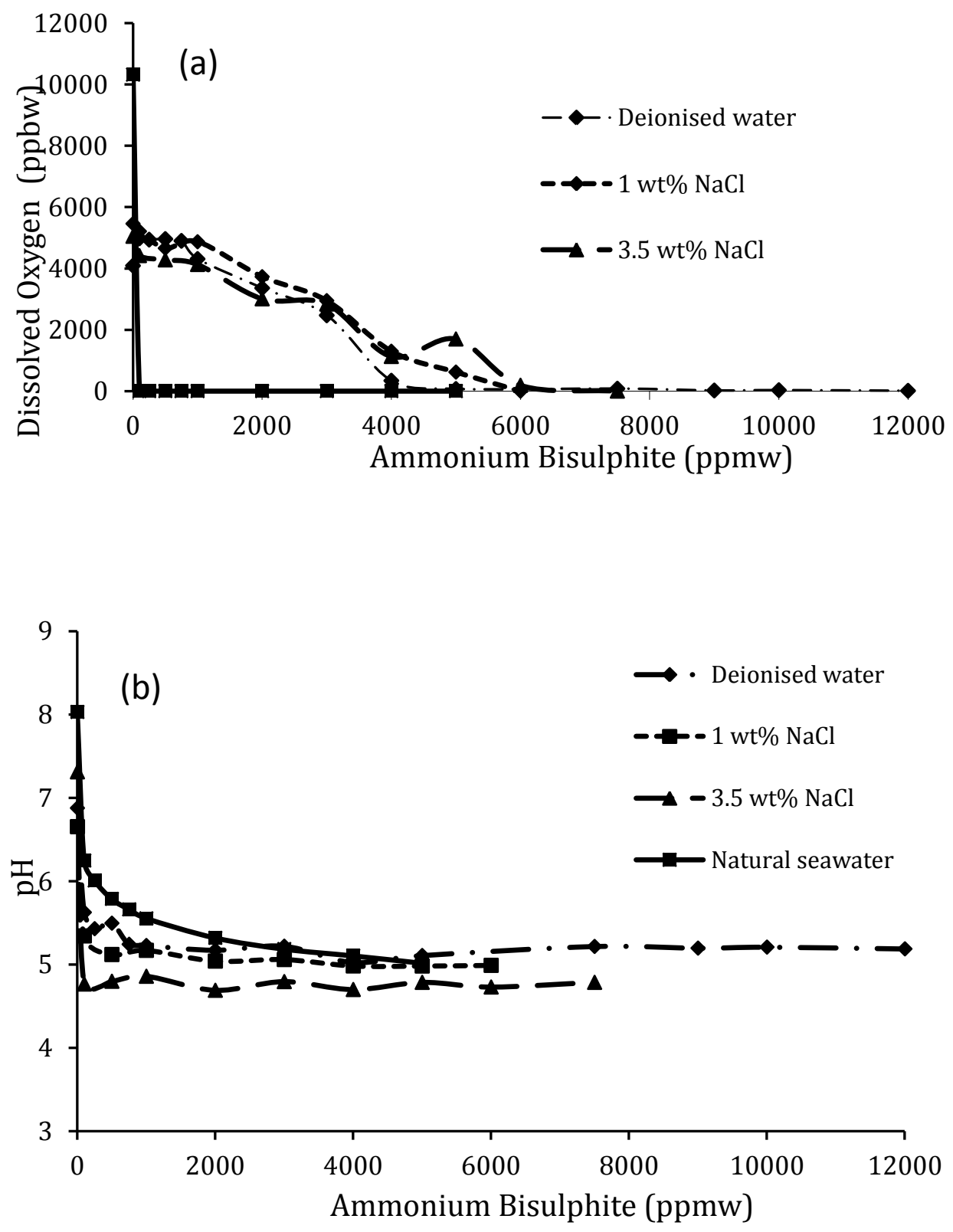

Figure 4 


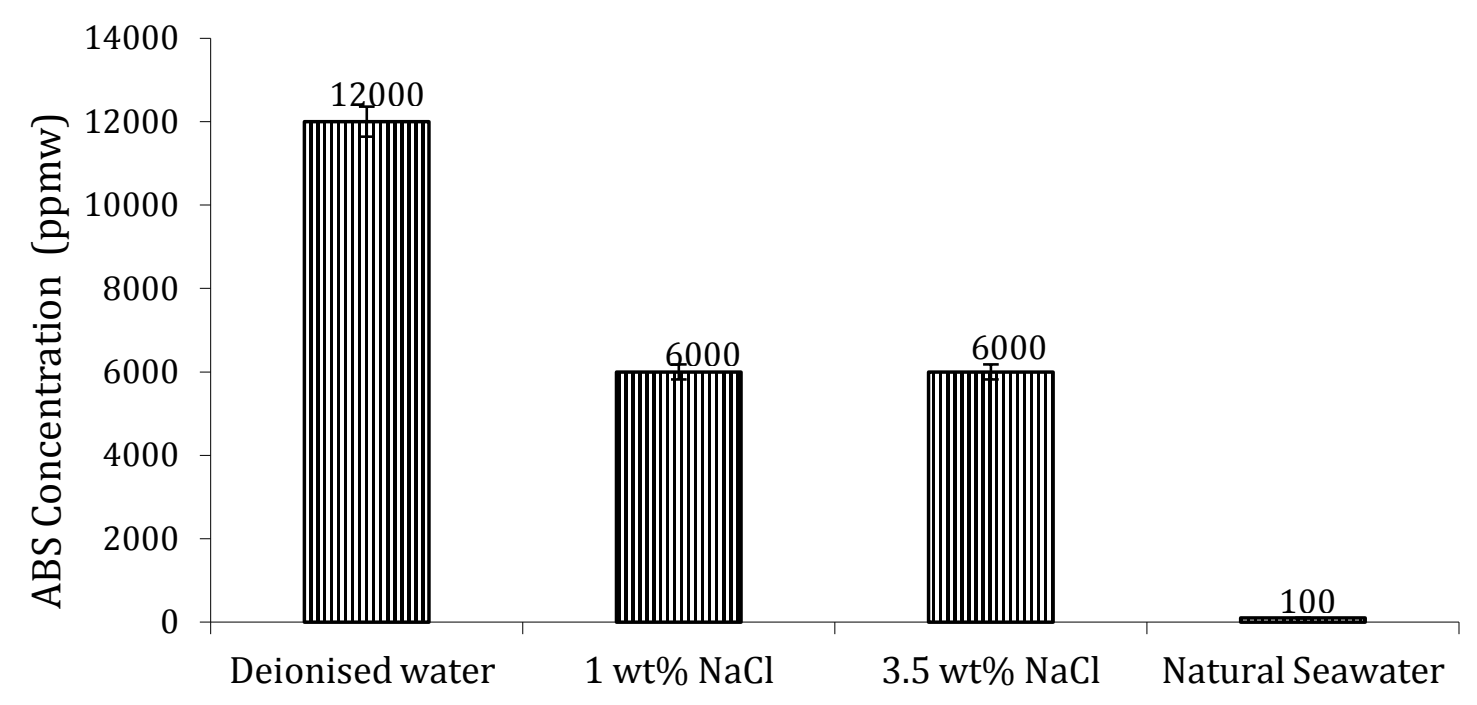

Figure 5 


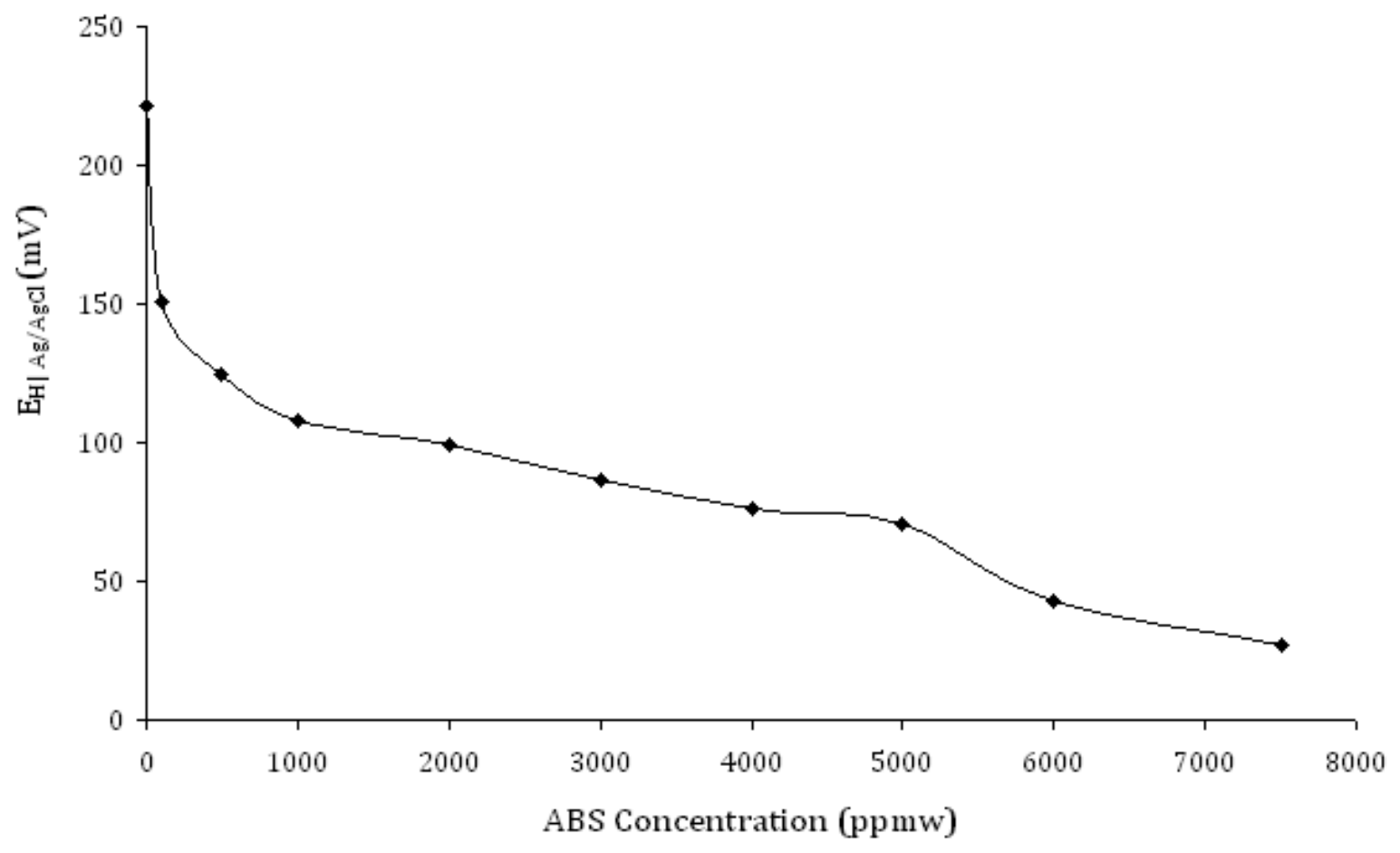

Figure 6 

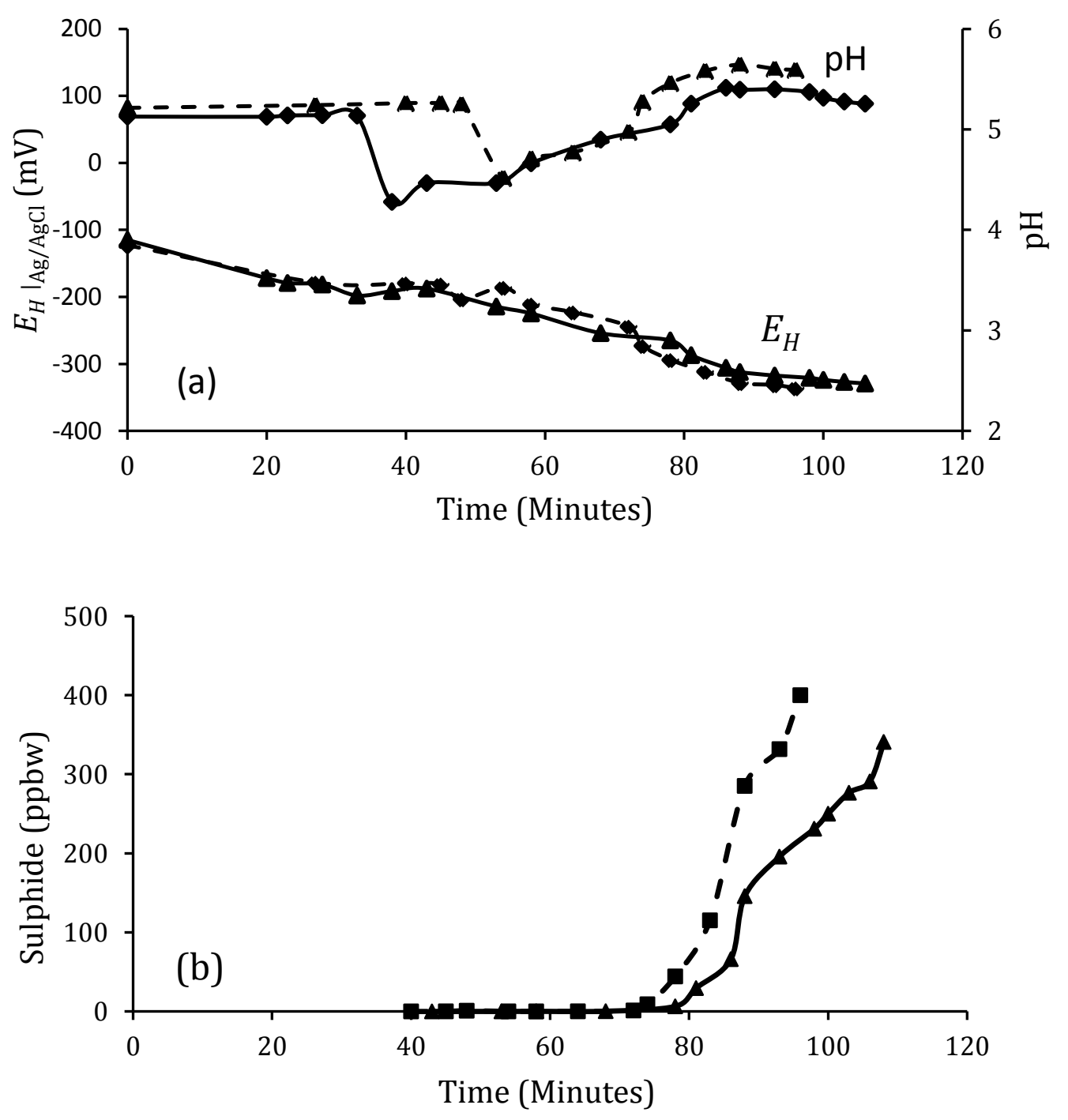

Figure 7 


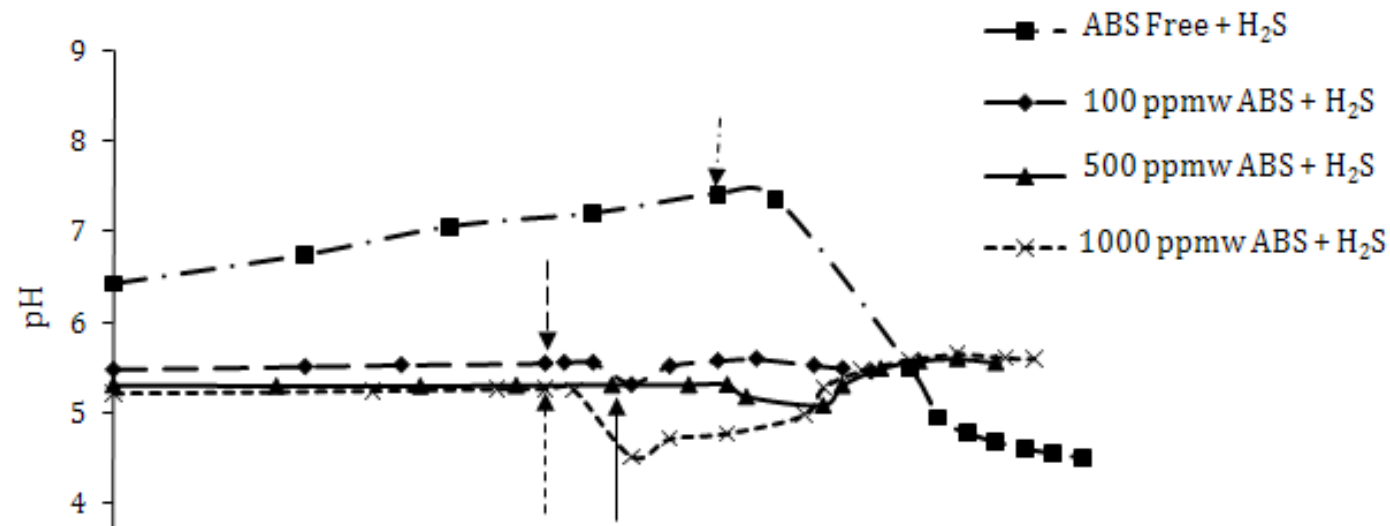

(a) Deionised water
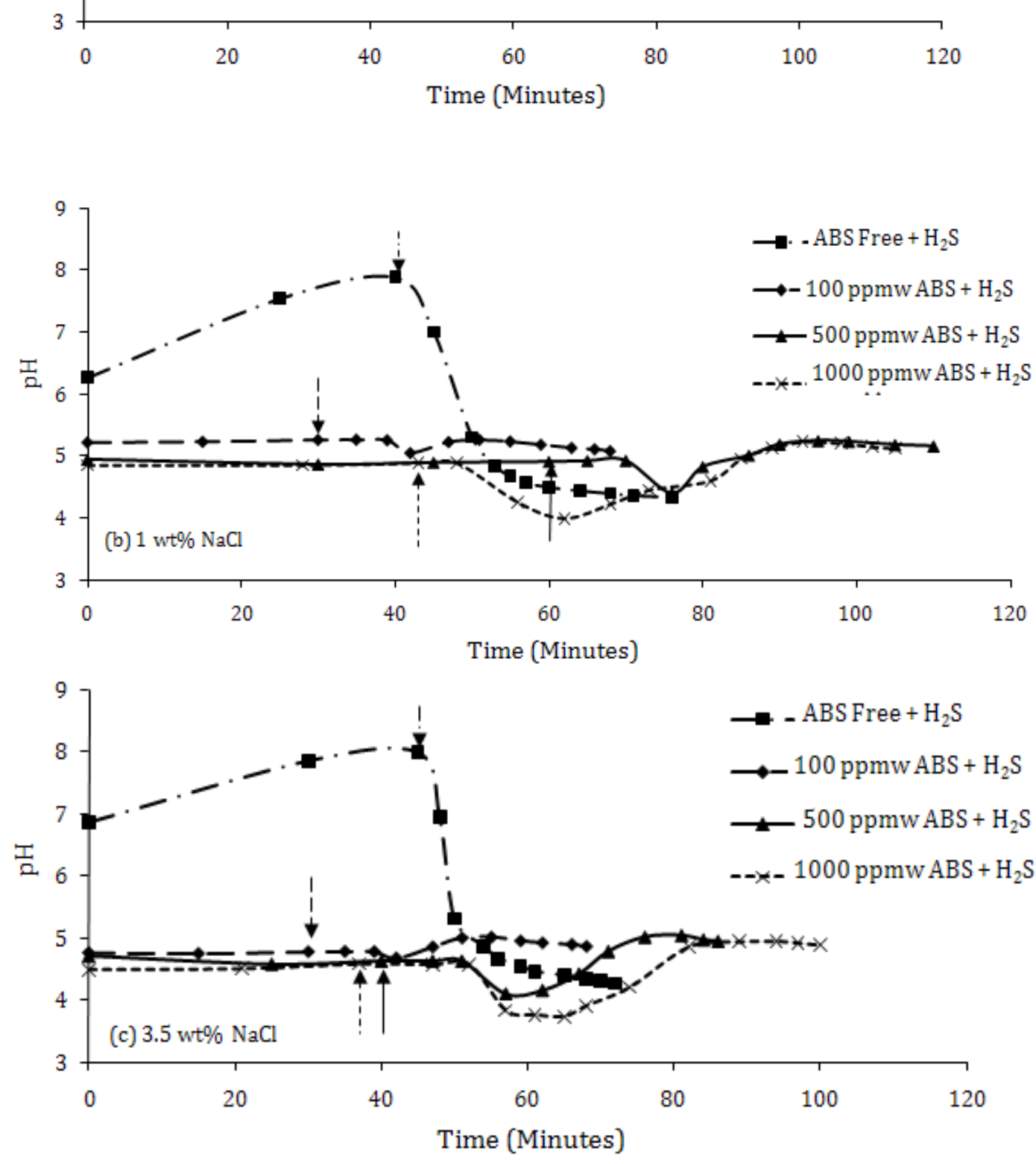

\section{Figure 8}



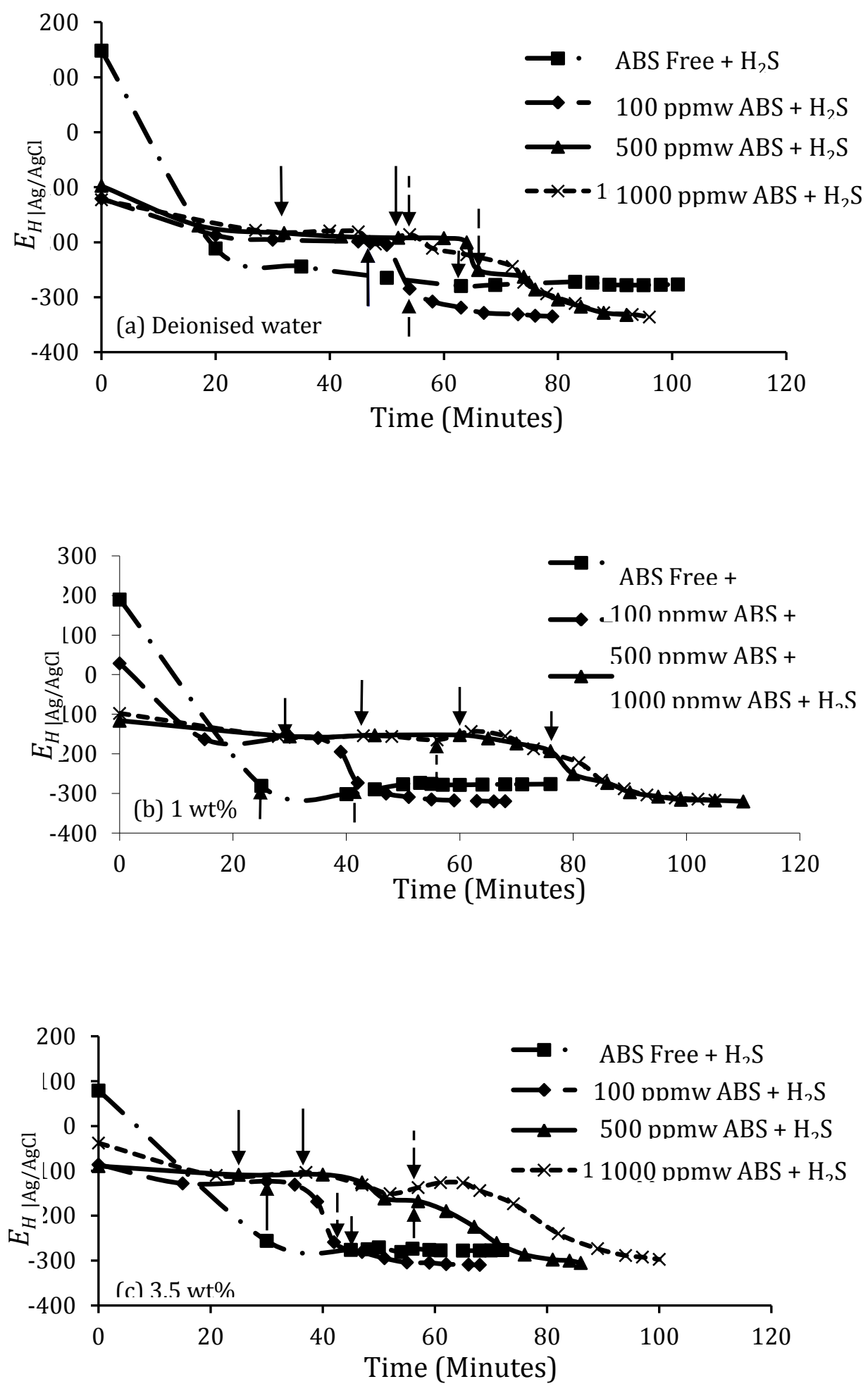

Figure 9 

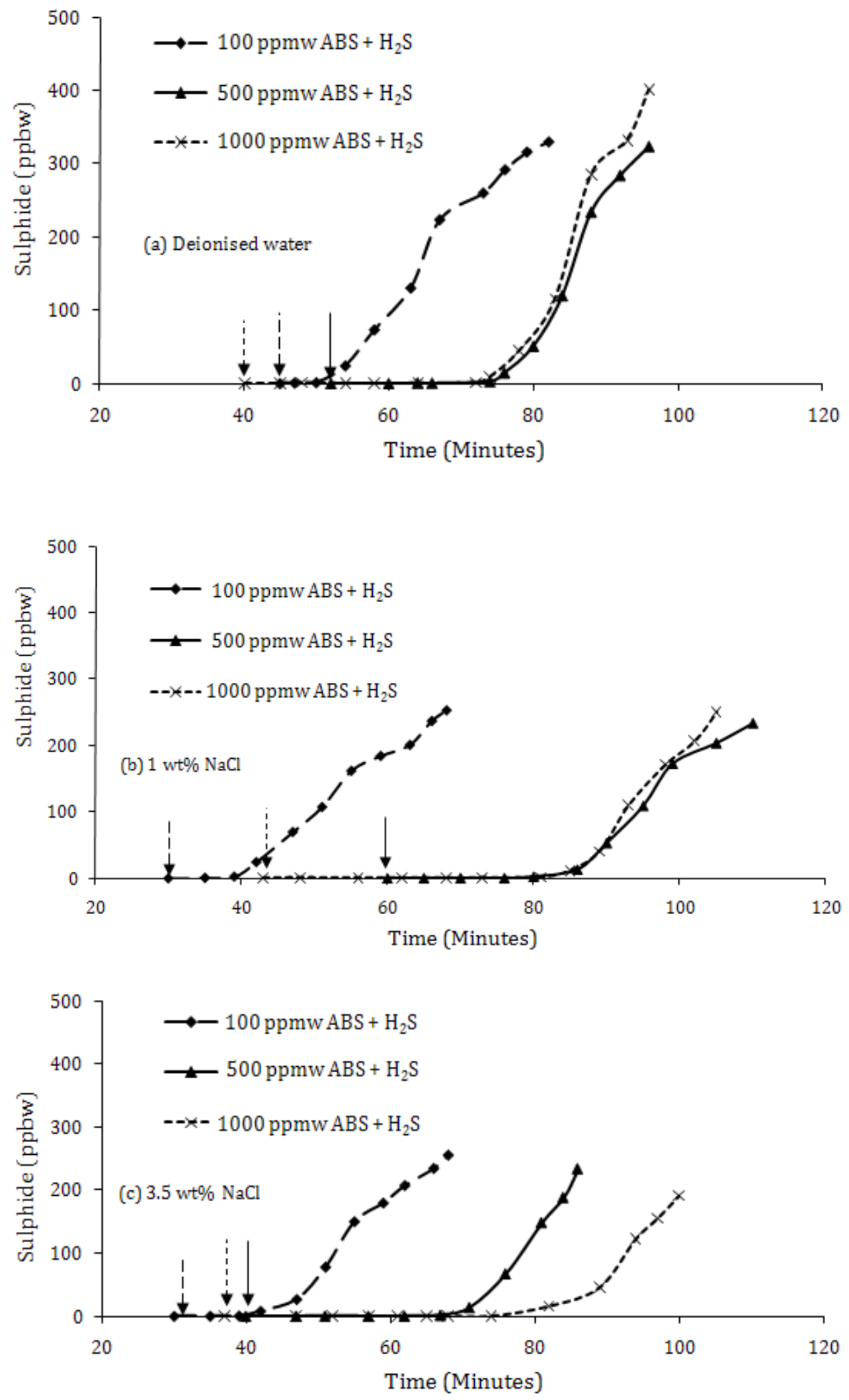

\section{Figure 10}




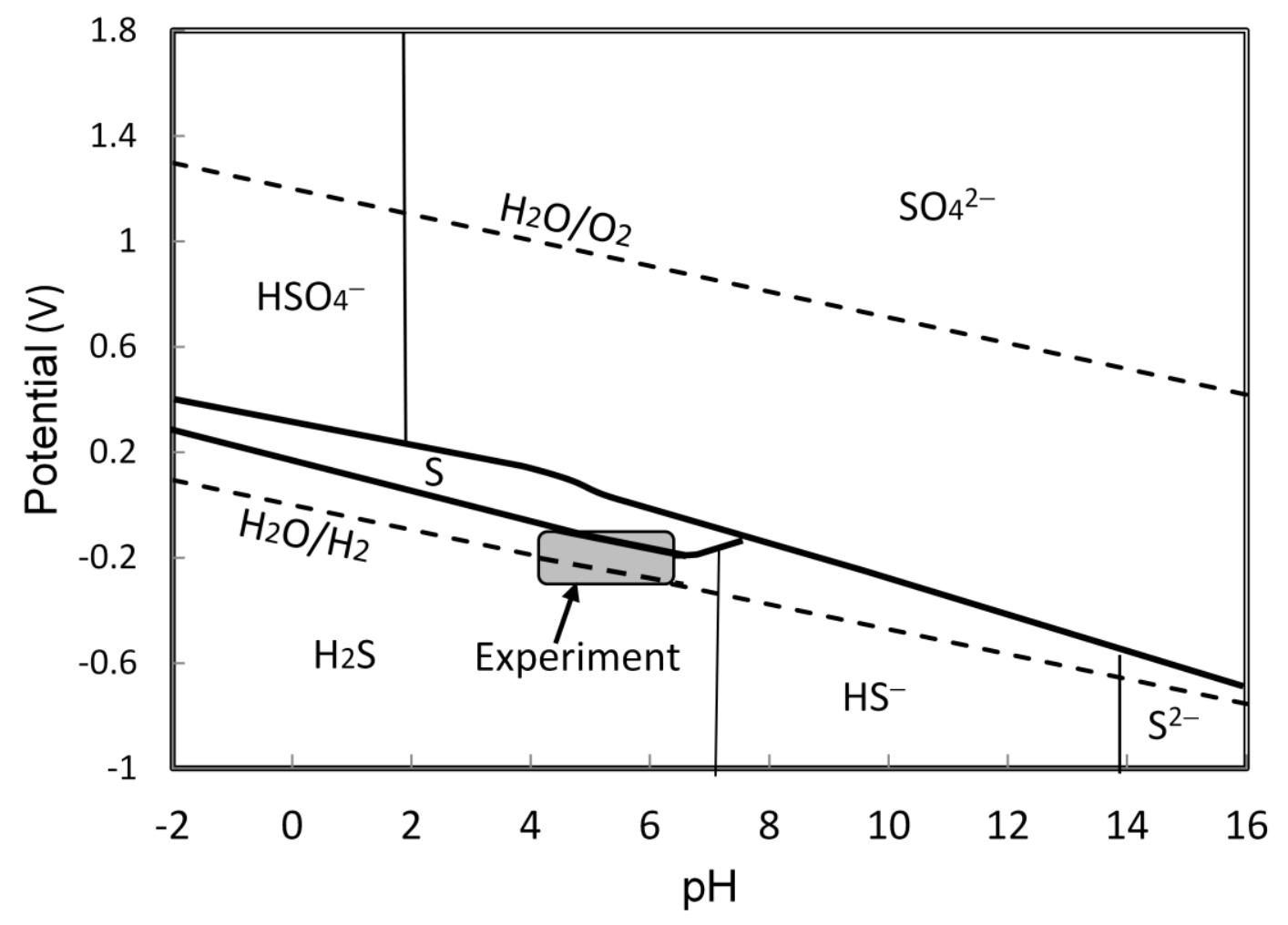

Figure 11 


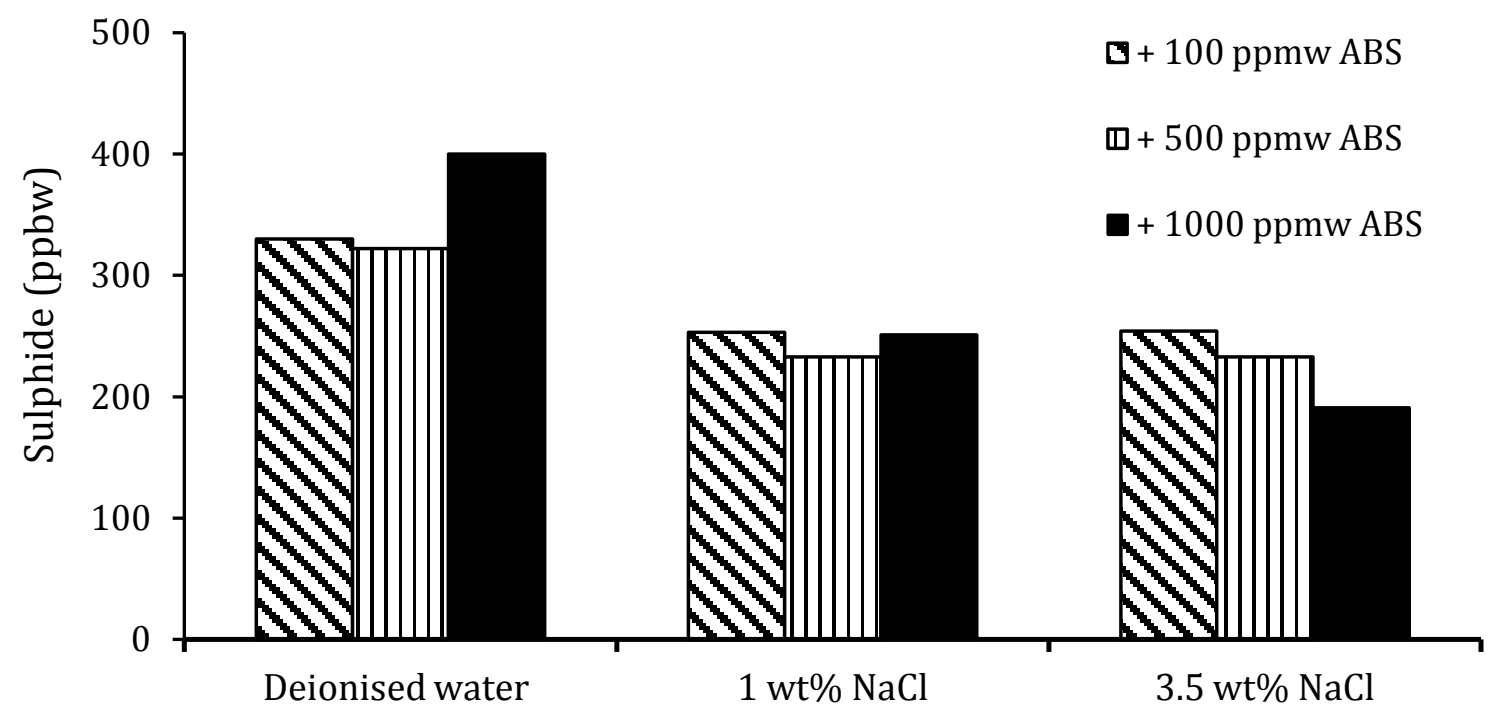

Figure 12 